\author{
BŁAŻEJCZYK KRZYSZTOF \\ Instytut Geografii i Przestrzennego Zagospodarowania PAN \\ Twarda 51/55, 00-818 Warszawa \\ k.blaz@twarda.pan.pl
}

\title{
WPŁYW ZMIAN KLIMATU NA WRAŻLIWE EKOSYSTEMY I SPOŁECZEŃSTWO. PRZEDMOWA
}

\begin{abstract}
Zmiany klimatu sa faktem, który niepokoi społeczność międzynarodowa. Postępujacy wzrost temperatury powietrza oraz częstości i intensywności ekstremalnych zjawisk pogodowych sa odczuwane przez wszystkich. Działajacy pod auspicjami ONZ Międzyrządowy Panel do Spraw Zmian Klimatu (IPCC) od ponad 30 lat gromadzi i analizuje informacje $z$ badań naukowych. Dotycza one zarówno samego zjawiska i jego możliwych przyczyn, jak również oddziaływania zmian klimatu na różne ekosystemy i różne sfery życia człowieka. W dyskursie naukowym większość badaczy zgadza się co do samego faktu istnienia zmian klimatu i ich konsekwencji. Nie do końca jednak naukowcy zgadzaja się co do tego, w jakim stopniu zmiany klimatu sa spowodowane czynnikami naturalnymi, a na ile antropogenicznymi. Jednak zdecydowanie przeważa pogląd, że to działalność człowieka (przede wszystkim: emisja gazów cieplarnianych, deforestacja, urbanizacja, industrializacja i rolnictwo) jest głównym źródłem zachodzących zmian.

W dyskursie społecznym powszechnie pojawiają się żądania, kierowane do gremiów politycznych, podjęcia zdecydowanych kroków, które pozwola zahamować lub przynajmniej ograniczyć tempo wzrostu temperatury. Dyskusje polityczne na ten temat sa prowadzone na corocznych Konferencjach Stron (Conferences of the Parties, COP), ktore sa najwyższym organem Ramowej Konwencji Narodów Zjednoczonych w sprawie zmian klimatu (United Nations Framework Convention on Climate Change, UNFCCC), uprawnionym do dokonywania przeglądów realizacji jej postanowień i przyjmowaniem zwiąanych $z$ konwencja instrumentów prawnych. W bieżącym roku 26 sesja COP odbyła się w Glasgow. Niestety, tak jak wiele poprzed-
\end{abstract}

nich spotkań COP, nie przyniosła ona znaczącego postępu w zakresie ochrony klimatu i ograniczenia jego zmian.

Redakcja KOSMOSU od kilkunastu lat włącza się do naukowej dyskusji na temat zmian klimatu. W 2008 r. ukazał się tom poświęcony globalnemu ociepleniu (Kosmos 57, 3-4, Globalne ocieplenie $i$ jego skutki) i jego skutkom, a w 2013 r. jeden $z$ artykułów czasopisma dedykowany był 25-leciu pracy IPCC (Kosmos 62, 1, 1-11). W obecnym numerze KOSMOSU czytelnik znajdzie 4 artykuły, które sa poświęcone oddziaływaniu zmian klimatu na funkcjonowanie wybranych, wrażliwych ekosystemów oraz na społecznie ważne zagadnienie ochrony zdrowia. Prezentowane teksty dotyczą różnych horyzontów czasowych. Najdłuższy $z$ nich obejmuje ostatnie 5 tysięcy lat. Dwa teksty prezentują współczesne zmiany klimatu zachodzace we wrażliwych ekosystemach (obszary polarne i bagienne). Ostatni $z$ tekstów sięga w przyszłość i odnosi się do możliwych konsekwencji zmian klimatu dla zdrowia społeczeństwa. W zamierzeniu miał jeszcze powstać tekst dotyczący zmian klimatu w obszarach wysokogórskich. Niestety, choroba autora uniemożliwiła jego przygotowanie.

Tekst K. Musliha i K Błażejczyka pokazuje różne czasowe spojrzenia na zmiany klimatu na pustynnym i półpustynnym obszarze Bliskiego Wschodu. Na podstawie różnych źródeł pośrednich Autorzy przedstawiają rozwój klimatu w okresie 3000-0 BC (przed Chrystusem). W okresie tym dokonywały się wielokrotnie wahania klimatu (od chłodnego do gorącego i od suchego do wilgotnego). Zmiany te miały istotny wpływ na rozwój społeczny, polityczny i gospodarczy tego obszaru, powodujacc wzrosty i upadki kilku cywilizacji rozwijajacych się na obsza- 
rze Mezopotamii. Niestabilność klimatu tego obszaru zaznacza się także współcześnie. Jej obrazem sa wahania opadów atmosferycznych i temperatury, a wpływ na te wahania maja, podobnie jak w okresie 3000-0 BC, zmiany cyrkulacji atmosferycznej, zarówno w obszarze północnego Atlantyku (wskaźnik NAO), jak i w północno-zachodnim rejonie Oceanu Indyjskiego. Wahania te maja także współcześnie wpływ na funkcjonowanie społeczeństw bliskowschodnich.

Tekst S. i M. Słowińskich dotyczy problemów funkcjonowania ekosystemów torfowych w strefie klimatu umiarkowanego i chłodnego. Na podstawie badań własnych i badań innych zespołów naukowych Autorzy przedstawiaja interakcje zachodzace pomiędzy obserwowanymi zmianami klimatu a funkcjonowaniem torfowisk. W rozważaniach swych sięgaja nie tylko do współczesnych procesów, ale próbują także dokonać rekonstrukcji tych zmian na podstawie badań paleoklimatycznych, wykorzystujacych wiercenia prowadzone w różnych obszarach półkuli północnej. Autorzy podkreślają, że dopiero integracja badań paleoklimatycznych i obserwacja współczesnych procesów pozwoli na określenie punktów zwrotnych i trajektorii zmian dla torfowisk.

Omówienia ważnego zagadnienia zmian klimatu w ekosystemach polarnych podjęła się grupa polskich polarników pod kierunkiem A. Araźnego. W swych rozważaniach wykorzystuja nie tylko wyniki badań historycznych i eksperymentalnych, ale także własne doświadczenia ze swych pobytów w Arktyce i Antarktyce. Zdaniem Autorów obserwowane zmiany klimatu $\mathrm{w}$ regionach polarnych wpływaja na ekosystemy lacdowe i morskie. Spodziewane konsekwencje ocieplania się Arktyki i Antarktyki „obejmuja m.in. redukcje grubości i powierzchni lądolodów kontynentalnych, zmniejszenie powierzchni lodowców górskich, ubytek powierzchni lodów morskich oraz wieloletniej zmarzliny i pokrywy śnieżnej. W wyniku deglacjacji zmienia się linia brzegowa i przybrzeżna obszarów lądowych". Zmiany klimatu, a zwłaszcza podwyższenie temperatury, powoduja zmiany $\mathrm{w}$ faunie i florze, przejawiajace się wkraczaniem na tereny polarne roślinności krzewiastej. Pozytywnym skutkiem ocieplania regionów polarnych jest natomiast polepszenie odczuwalnych warunków pogodowych dla człowieka.

Uzupełnieniem badań nad historycznymi i współczesnymi badaniami zmian klimatu jest spojrzenie na klimat w przyszłości. Dokonali tego A. Błażejczyk i J. Baranowski analizujac, jak zmieniajacy się klimat będzie w nadchodzacych dekadach XXI w. wpływał na stan zdrowia społeczeństwa w Polsce. Wykorzystali wyniki realizowanego przez siebie w latach 2012-2015 projektu Ocena wpływu zmian klimatu na stan zdrowia społeczeństwa $w$ różnych regionach Polski oraz prognoza do roku 2100. Badania te opieraja się na schemacie retrospekcyjno-prognostycznym. Na podstawie danych historycznych Autorzy opracowali statystyczne modele oddziaływania różnych cech klimatu na liczbę zachorowań i zgonów na tzw. choroby klimatozależne. W drugim etapie wykorzystali prognozy zmian klimatu według scenariuszy SRES (A1, A1B i B2) zakładajacych różne tempo zmian klimatu. Stwierdzili jak istotne statystycznie bęa wzrosty takich chorób jak: nowotwory skóry, borelioza czy zgony $z$ przyczyn kardiologicznych i zwiąane ze stresem goraca. Należy także oczekiwać spadku liczby infekcji grypowych i zgonów $z$ powodu chorób układu oddechowego.

$\mathrm{Na}$ znaczenie klimatu i jego zmian w funkcjonowaniu wrażliwych ekosystemów i społeczeństw ponownie zwraca uwagę udostępniony niedawno 6 Raport IPCC. Wnioski $\mathrm{z}$ przedstawionych $\mathrm{w}$ obecnym zbiorze badań sa także wyraźnie podkreślone w tym Raporcie. Odnośnie ekosystemów górskich kolejne raporty IPCC, także ten najnowszy, stwierdzaja, że sa one narażone na cały szereg wyzwań wynikajacych ze zmian klimatu, a wpływających na zmiany piętrowości klimatycznej i roślinnej, w tym zagrożeń dla endemicznych, górskich gatunków roślin. Wyzwania te wiążą się $z$ postępującym wzrostem temperatury, ubytkami pokrywy śnieżnej i lodowców górskich czy też zwiększeniem ekstremalnych opadów i wywołanych nimi powodzi błyskawicznych. Zmiany te maja charakter globalny i sa obserwowane na wszystkich kontynentach

Przedstawiony zbiór tekstów nie wyczerpuje oczywiście całości zagadnienia wpływu klimatu na funkcjonowanie wrażliwych ekosystemów i na funkcjonowanie społeczeństw. Wierzymy jednak, że dobitnie mówia one o konieczności zintensyfikowania działań społeczności międzynarodowej w kierunku zahamowania, a przynajmniej spowolnienia zmian klimatu. W przeciwnym razie grozi nam zniszczenie bioróżnorodności ekosystemów oraz kosztowne społecznie i ekonomicznie wysiłki zapewnienia przyszłym pokoleniom możliwości życia i rozwoju.

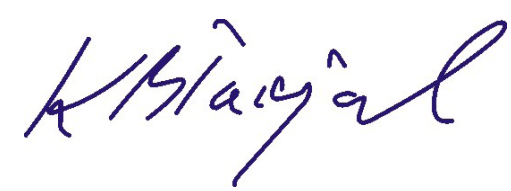

